\title{
Effect of Financial Performance on Dividend Policy in Manufacturing Companies in Indonesia Stock Exchange
}

\author{
Delfian Rian Zaman \\ STIE Prakarti Mulya \\ delfianzaman@gmail.com
}

\begin{abstract}
This study aims to examine the effect of cash ratio, debt to equity ratio, and return on the asset to dividend payout ratio on manufacturing companies listed on Indonesia Stock Exchange with observation period 2010-2014. The sampling technique used is purposive sampling so that the number of samples is 27 companies. The analysis technique used in this research is multiple linear regression and hypothesis test using $t$-statistic to test partial regression coefficient and $f$ statistic to test the feasibility of research model with a level of significance 5\%. Besides, there is also a classic assumption test that includes normality test, multicollinearity test, heteroscedasticity test and autocorrelation test. The result of the analysis shows that the variables of cash ratio and return on asset have positive and significant influence, while the variable of debt to equity ratio has a negative and significant effect to dividend payout ratio.
\end{abstract}

Keywords: Cash Ratio, Debt to Equity Ratio, Return On Asset, Dividend Payout Ratio.

\section{Pendahuluan}

Cash ratio berpengaruh positif dan signifikan terhadap dividend payout ratio. Hal ini berarti setiap peningkatan nilai cash ratio maka pada umumnya akan terjadi pula peningkatan pada nilai dividend payout ratio. Jumlah kas dan setara kas yang dipunyai perusahaan juga secara tidak langsung akan mencerminkan kemampuan perusahaan untuk membagi dividen kepada para pemegang saham. Debt to equity ratio berpengaruh negatif dan signifikan terhadap dividend payout ratio. Hal ini berarti dengan rendahnya nilai debt to equity ratio perusahaan maka pada umumnya kemampuan perusahaan untuk membayar dividen akan semakin tinggi. Peningkatan dan penurunan hutang sangat mempengaruhi jumlah laba bersih yang pada akhirnya akan mempengaruhi nilai laba ditahan yang tercatat, jika nilai hutang tinggi tentu saja akan mempengaruhi kemampuan perusahaan untuk membagikan dividen. Return on asset berpengaruh signifikan terhadap dividend payout ratio. Hal ini bermakna bahwa setiap kenaikan nilai return on asset maka pada umumnya akan meningkatkan kemampuan perusahaan untuk membayarkan dividen kepada pemegang saham. Ini disebabkan karena meningkatnya kemampuan profitabilitas perusahaan maka akan diikuti kemampuan perusahaan dalam menghasilkan laba bersih yang tinggi, yang pada akhirnya akan mempengaruhi jumlah dividen yang akan dibagikan kepada para pemegang saham.

\section{Rumusan Masalah}

1. Seberapa besar pengaruh Likuiditas Cash Ratio terhadap Dividen Payout Ratio?

2. Seberapa besar pengaruh Leverage debt to equity ratio terhadap Dividen Payout Ratio? 
IJBE: Integrated Journal of Business and Economics

e-ISSN: 2549-3280

3. Seberapa besar pengaruh Profitabilitas Return On Aset terhadap Dividen Payout Ratio?

\section{Hipotesis}

1. Terdapat pengaruh Likuiditas Cash Ratio terhadap kebijakan Dividen Payout Ratio?

2. Terdapat pengaruh Leverage Debt to Equity Ratio terhadap kebijakan Dividen Payout Ratio?

3. Terdapat pengaruh Profitabilitas Return On Aset terhadap kebijakan Dividen Payout Ratio?

\section{Kajian Pustaka}

\section{Rasio Likuiditas}

Menurut Kasmir (2012:130), Rasio likuiditas atau sering juga disebut dengan nama rasio modal kerja merupakan rasio yang digunakan untuk mengukur seberapa likuidnya suatu perusahaan. Caranya adalah dengan membandingkan komponen yang ada di neraca, yaitu total aktiva lancar dengan total passiva lancar (utang jangka pendek). Penilaian dapat dilakukan untuk beberapa periode sehingga terlihat perkembangan likuiditas perusahaan dari waktu ke waktu.

Tujuan dan manfaat rasio likuditas untuk perusahaan menurut Kasmir (2012:132) adalah sebagai berikut:

1. Untuk mengukur kemampuan perusahaan membayar kewajiban atau utang yang secara jatuh tempo pada saat ditagih. Artinya, kemampuan untuk membayar kewajiban yang sudah waktunya dibayar sesuai jadwal batas waktu yang telah ditetapkan (tanggal dan bulan tertentu).

2. Untuk mengukur kemampuan perusahaan membayar kewajiban jangka pendek dengan aktiva lancar secara keseluruhan. Artinya jumlah kewajiban yang berumur di bawah satu tahun atau sama dengan satu tahun, dibandingkan dengan total ktiva lancar.

3. Untuk mengukur kemampuan perusahaan membayar kewajiban jangka pendek dengan aktiva lancar tanpa memperhitungkan sediaan atau piutang. Dalam hal ini aktiva lancar dikurangi sediaan dan utang yang dianggap likuiditasnya lebih rendah.

4. Untuk mengukur atau membandingkan antara jumlah sediaan yang ada dengan modal kerja perusahaan.

5. Untuk mengukur seberapa besar uang kas yang tersedia untuk membayar utang.

6. Sebagai alat perencanaan ke depan, terutama yang berkaitan dengan perencanaan kas dan utang.

7. Untuk melihat kondisi dan posisi likuiditas perusahaan dari waktu ke waktu dengan membandingkannya untuk beberapa periode.

8. Untuk melihat kelemahan yang dimiliki perusahaan, dari masing-masing komponen yang ada di aktiva lancar dan utang lancar.

9. Menjadi alat pemicu bagi pihak manajemen untuk memperbaiki kinerjanya, dengan melihat rasio likuiditas yang ada pada saat ini.

Bagi pihak luar perusahaan, seperti pihak penyandang dana (kreditor), investor, istributor, dan masyarakat luas, rasio likuiditas bermanfaat untuk menilai kemampuan perusahaan dalam membayar kewajiban kepada pihak ketiga.

Jenis-jenis rasio likuiditas adalah sebagai berikut: 
1. Rasio lancar (current ratio) menurut Kasmir (2012:134) adalah sebagai berikut:

Rasio lancar atau current ratio merupakan rasio untuk mengukur kemampuan perusahaan dalam membayar kewajiban jangka pendek atau utang yang segera jatuh tempo pada saat ditagih secara keseluruhan. Dengan kata lain, seberapa banyak aktiva lancar yang tersedia untuk menutupi kewajiban jangka pendek atau utang yang segera jatuh tempo.

Rumus untuk mencari rasio lancar atau current ratio dapat yang digunakan sebagai berikut :

$$
\text { Current Ratio }(C R)=\frac{\text { Aktiva Lancar }(\text { Current Assets })}{\text { Kewajiban Lancar }(\text { Current Liabilities })}
$$

2. Rasio Kas (Cash Ratio) menurut Kasmir (2012:138) adalah sebagai berikut :

Rasio kas atau (cash ratio) merupakan alat yang digunakan untuk mengukur seberapa besar uang kas yang tersedia untuk membayar utang. Ketersediaan uang kas dapat ditunjukkan dari tersedianya dana kas atau setara dengan kas seperti rekening giro atau tabungan di bank (yang dapat ditarik setiap saat). Dapat dikatakan rasio ini menunjukkan kemampuan sesungguhnya bagi perusahaan untuk membayar utang-utang jangka pendeknya.

Rumus untuk mencari rasio kas atau cash ratio dapat digunakan sebagai berikut:

$$
\text { Cast Ratio }(C R)=\frac{\text { Kas }+ \text { Bank }}{\text { Kewajiban Lancar }}
$$

\section{Rasio Leverage}

Rasio Leverage adalah mengukur kemampuan perusahaan untuk memenuhi kewajiban finansialnya yang terdiri dari utang jangka pendek dan utang jangka panjangnya. Data yang digunakan untuk menilai leverage dalam penelitian ini adalah laporan keuangan pada perusahaan manufakur yang secara berturut-turut membagikan dividen pada tahun 2010-2014 yang diperoleh melalui (www.idx.co.id). Leverage didalam penelitian ini diwakili oleh debt to equity ratio. Debt to equity ratio adalah rasio yang merupakan perbandingan antara total utang dengan modal sendiri. Secara matematis, debt to equity ratio dapat dihitung dengan menggunakan rumus sebagai berikut :

$$
\text { Debt to Equity Ratio }=\frac{\text { Total Utang }}{\text { Total Modal Sendiri }}
$$

\section{Rasio Profitabilitas}

Menurut Kasmir (2012:196) Rasio profitabilitas merupakan rasio untuk menilai kemampuan perusahaan dalam mencari keuntungan. Rasio ini juga memberikan ukuran tingkat efektivitas manajemen suatu perusahaan. Hal ini ditunjukkan oleh laba yang dihasilkan dari penjualan dan pendapatan investasi. Intinya adalah enggunaan rasio ini menunjukkan efisiensi perusahaan.

Tujuan penggunaan rasio profitabilitas bagi perusahaan, maupun bagi pihak luar perusahaan, yaitu: 
1. Untuk mengukur atau menghitung laba yang diperoleh perusahaan dalam satu periode tertentu.

2. Untuk menilai posisi laba perusahaan tahun sebelumnya dengan tahun sekarang.

3. Untuk menilai perkembangan laba dari waktu ke waktu.

4. Untuk menilai besarnya laba bersih sesudah pajak dengan modal sendiri.

5. Untuk mengukur produktivitas seluruh dana perusahaan yang digunakan baik modal pinjman maupun modal sendiri.

6. Untuk mengukur produktivitas dari seluruh dana perusahaan yang digunakan baik modal sendiri.

Jenis- jenis rasio profitabilitas adalah sebagai berikut:

1. Margin Laba Bersih (Net Profit Margin) menurut Kasmir (2012:200) Margin laba bersih merupakan ukuran keuntungan dengan membandingkan antara laba setelah bunga dan pajak dibandingkan dengan penjualan. Rasio ini menunjukkan pendapatan bersih perusahaan atas penjualan.

Rumus untuk menghitung margin laba bersih (net profit margin) adalah sebagai berikut:

$$
\text { Net Profit Margin }=\frac{\text { Earning After Interest and Tax }}{\text { Sales }}
$$

2. Hasil Pengembalian Investasi (Return On Investment/ROI) menurut Kasmir (2012:201) adalah sebagai berikut:

Hasil pengembalian investasi atau lebih dikenal dengan nama return on investment (ROI) atau return on assets (ROA) merupakan rasio yang menunjukkan hasil (return) atas jumlah aktiva yang digunakan dalam perusahaan. ROI juga merupakan suatu ukuran tentang efektivitas manajemen dalam mengelola investasinya. Semakin kecil rasio ini semakin kurang baik, demikian pula sebaliknya. Artinya rasio ini digunakan untuk mengukur efektivitas dari keseluruhan operasi perusahaan.

Rumus untuk mencari return on investment (ROI) adalah sebagai berikut :

$$
\text { Return On Investment }=\frac{\text { Earning After Interest and Tax }}{\text { Total Assets }}
$$

3. Hasil Pengembalian Ekuitas (Return On Equity/ROE) menurut Kasmir (2012:201) adalah sebagai berikut:

Hasil pengembalian ekuitas (return on equity/ROE) atau rentabilitas modal sendiri merupakan rasio untuk mengukur laba bersih sesudah pajak dengan modal sendiri. Rasio ini menunjukkan efisiensi penggunaan modal sendiri. Semakin tinggi rasio ini, semakin baik. Artinya posisi pemilik perusahaan semakin kuat, demikian pula sebaliknya.

Rumus untuk mencari return on equity (ROE) adalah sebagai berikut: 
IJBE: Integrated Journal of Business and Economics

e-ISSN: 2549-3280

$$
\text { Return On Equity }(\mathrm{ROE})=\frac{\text { Earning After Interest and Tax }}{\text { Equity }}
$$

\section{Dividen}

Dividen adalah pembagian laba kepada pemegang saham berdasarkan banyaknya saham yang dimiliki. Pembagian ini akan mengurangi laba di tahan dan kas yang tersedia bagi perusahaan, tapi distribusi keuntungan kepada para pemilik memang adalah tujuan utama suatu bisnis. Menurut Stice et al (2004:902) Dividen adalah pembagian kepada pemegang saham dari suatu perusahaan secara proporsional sesuai dengan jumlah saham yang dipegang oleh masing-masing pemilik. Sementara menurut Skousen et al (2001:757) yang dikutip oleh Manurung dan Siregar (2008:3) Dividen adalah pendistribusian laba secara proporsional kepada para pemegang saham sesuai dengan jumlah saham yang dimilikinya.

Menurut Martono dan Harjito (2005:253), menyatakan bahwa "Kebijakan dividen merupakan keputusan apakah laba yang diperoleh perusahaan pada akhir tahun akan dibagi kepada pemegang saham dalam bentuk dividen atau akan ditahan untuk menambah modal guna pembiayaan investasi di masa yang akan datang". Warsono (2003:271) menjelaskan, Dividen merupakan bagian dari laba yang tersedia bagi pemegang saham biasa (earning available for common stockholder) yang dibagikan kepada para pemegang saham. Hanafi (2004:361), mengemukakan bahwa Dividen merupakan kompensasi yang diterima oleh pemegang saham, disamping capital gain. Dividen ini untuk dibagikan kepada para pemegang saham sebagai dari keuntungan dari laba perusahaan. Dyckman, et al. (2001: 439) menjelaskan bahwa dividen merupakan distribusi laba kepada pemegang saham dalam bentuk aktiva atau saham perusahaan penerbit. Berdasarkan pendapat-pendapat tersebut maka dapat disimpulkan bahwa dividen merupakan bagian laba yang dihasilkan oleh perusahaan, baik berasal dari laba periode saat ini ataupun laba periode sebelumnya yang dibagikan kepada pemegang saham sebagai hasil atas investasi.

Menurut Warsono (2003:275), indikator untuk mengukur kebijakan dividen yang secara luas digunakan ada dua macam, yaitu:

1. Hasil Dividen (Dividend Yield). Dividend Yield adalah suatu rasio yang menghubungkan dividen yang dibayar dengan harga saham biasa. Dividend Yield menyediakan suatu ukurankomponen pengembalian total yang dihasilkan dividen, dengan menambahkan apresiasi harga yang ada. Beberapa investor menggunakan dividend yield sebagai suatu ukuran risiko dan sebagai suatu penyaring investasi, yaitu mereka akan berusaha menginvestasikan dananya dalam saham yang menghasilkan dividend yield yang tinggi.

2. Rasio Pembayaran Dividen (Dividend Payout Ratio/DPR)

DPR merupakan rasio hasil perbandingan antara dividen dengan laba yang tersedia bagi para pemegang saham biasa. DPR banyak digunakan dalam penilaian sebagai cara pengestimasian dividen untuk periode yang akan datang, sedangkan kebanyakan analis mengestimasikan pertumbuhan dengan menggunakan laba ditahan lebih baik daripada dividen

\section{Metode Penelitian}


Metode Penelitian ini untuk memperoleh gambaran tentang cash ratio, debt to equity ratio dan retun on assets kebijakan dividen serta mengukur pengaruh kinerja keuangan terhadap kebijakan dividen melalui pengujian hipotesis. Metode penelitian yang digunakan adalah deskriptif dan verifikatif. Penelitian deskriptif adalah penilitan yang bertujuan mendapatkan gambaran tentang ciri-ciri variable penelitian sedangkan sifat penelitian verifikatif pada dasarnya ingin menguji kebenaran suatu hipotesis yang dilaksanakan melalui pengumpulan data di lapangan. Dalam penelitian ini akan menguji pengaruh kinerja keuangan terhadap kebijakan dividen pada perusahaan manufaktur di bursa efek Indonesia.

Tipe penelitian ini adalah kausalitas, yaitu tipe penelitian adanya hubungan sebab akibat antara variable bebas (independent variable) dan variable terikat (depedent variable). Unit analisis dalam penelitian ini adalah perusahaan manufaktur yang terdaftar di Bursa Efek Indonesia (BEI), melalui website : www.idx.co.id dan melalui situs-situs resmi perusahaan. Data dalam penelitian ini menurut jenisnya merupakan data kuantitatif, yaitu data yang diukur dalam suatu skala numerik (angka). Menurut sumbernya, data dalam penelitian ini adalah data sekunder yang diperoleh melalui laporan tertulis berupa laporan keuangan perusahaan yang terdiri dari Neraca, Laporan Rugi/Laba, dan Laporan Perubahan Modal/Ekuitas yang diperoleh dari Bursa Efek Indonesia. Laporan Keuangan yang menjadi objek analisis diambil selama kurun waktu 20102014.

\section{Populasi dan Sample}

Populasi adalah wilayah generalisasi yang terdiri atas objek atau subjek yang mempunyai kualitas dan karakteristik tertentu yang ditetapkan oleh peneliti untuk dipelajari dan kemudian ditarik kesimpulannya (Sugiyono, 2008). Dalam penelitian ini populasinya adalah perusahaanperusahaan yang terdaftar di BEI pada tahun 2010-2014. Periode 2010-2014 (5 tahun) digunakan sebagai periode pengamatan karena dengan rentang waktu tersebut diharapkan akan didapatkan jumlah sampel penelitian yang cukup dan dapat digeneralisasi. Sampel adalah bagian dari jumlah dan karakteristik yang dimiliki oleh populasi tersebut (Sugiyono, 2008). Sampel dalam penelitian ini dipilih dengan metoda purposive sampling dengan menggunakan kriteria sebagai berikut. :

1. Perusahaan manufaktur yang terdaftar di BEI berturut-turut dari tahun 2010-2014.

2. Perusahaan yang menerbitkan laporan keuangannya untuk periode yang berakhir 31 Desember.

3. Perusahaan yang membagikan dividen lima tahun berturut-turut dari tahun 2010-2014.

Berdasarkan data dari ICMD perusahaan manufaktur yang terdaftar di BEI adalah 170 perusahaan. Perusahaan-perusahaan tersebut diseleksi kembali sesuai dengan kriteria purposive sampling yang telah ditetapkan sebelumnya. Seleksi sampel penelitian disajikan pada Tabel 1 berikut ini.

Tabel 1. Seleksi Sampel Penelitian

\begin{tabular}{|c|l|c|}
\hline No. & \multicolumn{1}{|c|}{ Kriteria } & Jumlah \\
\hline 1. & $\begin{array}{l}\text { Perusahaan manufaktur yang terdaftar di BEI berturut- } \\
\text { turut dari tahun 2010-2014 }\end{array}$ & 170 \\
\hline 2. & $\begin{array}{l}\text { Perusahaan yang tidak menerbitkan laporan keuangannya } \\
\text { untuk periode yang berakhir pada 31 Desember }\end{array}$ & (1) \\
\hline
\end{tabular}


IJBE: Integrated Journal of Business and Economics e-ISSN: 2549-3280

\begin{tabular}{|c|l|c|}
\hline 3. & $\begin{array}{l}\text { Perusahaan yang tidak membagikan dividen lima tahun } \\
\text { berturut-turut dari 2010-2014. }\end{array}$ & (57) \\
\hline & Jumlah sample akhir & 27 \\
\hline & Jumlah Pengamatan & 135 \\
\hline
\end{tabular}

Sumber: Data peneliti, 2014

Pada tabel 1 menunjukkan bahwa dari 170 perusahaan manufaktur yang terdaftar di BEI dari tahun 2010-2014 hanya terpilih 27 perusahaan yang akan digunakan sebagai sampel penelitian dan jumlah pengamatan sebanyak 108 pengamatan.

\section{Metode Analisis Data}

Data yang diperoleh dari hasil penelitian dianalisis dengan menggunakan metode deskriptif kuantitatif. Metode deskriptif bertujuan untuk menuturkan dan menafsirkan data yang berkenaan dengan situasi yang terjadi secara sistematis, faktual dan akurat mengenai fakta-fakta serta hubungan antar variabel untuk mendapatkan kebenaran, sedangkan metode kuantitatif bertujuan untuk mengangkat fakta, keadaan variabel, dan fenomena-fenomena yang terjadi saat sekarang dan menyajikan apa adanya (Sugiyono 2012). Adapun kriteria-kriteria yang harus dianalisis dalam penelitian ini dijelaskan pada sub bab berikutnya.

\section{Pembahasan Hasil}

\section{Statistik Deskriptif}

Statistik deskriptif dalam penelitian ini disajikan untuk memberikan informasi karakteristik variabel penelitian khususnya mengenai mean dan deviasi standar. Pengukuran mean merupakan cara yang paling umum digunakan untuk mengukur nilai sentral dari suatu distribusi data. Deviasi standar merupakan perbedaan antara nilai data yang diteliti dengan nilai rata-ratanya. Berikut ini disajikan hasil statistik deskriptif pengujian pengaruh cash ratio, debt to equity ratio, dan return on asset terhadap dividend payout ratio pada Tabel 2 berikut ini.

Tabel 2. Statistik Deskriptif

\begin{tabular}{|l|r|r|r|r|r|}
\hline & $\mathrm{N}$ & Minimum & Maximum & \multicolumn{1}{c|}{ Mean } & Std. Deviation \\
\hline CR & 135 &, 07 & 57,73 & 2,9789 & 5,10583 \\
DER & 135 &, 14 & 3,24 &, 8300 &, 67565 \\
ROA & 135 & $-1,52$ & 78,64 & 15,8411 & 14,06736 \\
DPR & 135 &, 68 & 141,55 & 39,3160 & 22,34825 \\
Valid N (listwise) & 135 & & & & \\
\hline
\end{tabular}

Sumber: Data peneliti diolah, 2014.

Berdasarkan hasil perhitungan pada tabel 2 tersebut nampak bahwa dari perusahaan dengan sampel sebanyak 135 pengamatan, nilai rata-rata DPR selama periode pengamatan sebesar 39,3160 dengan standar deviasi sebesar 22,34825. Hasil itu menunjukkan bahwa nilai standar deviasi lebih kecil dari rata-rata DPR, demikian pula jarak yang cukup besar antara nilai minimum dan maximum dari DPR dimana nilai minimum sebesar 0,68 dan nilai maksimum sebesar 141,55. Hasil yang sama juga didapat oleh variabel cash ratio sedangkan untuk variabel debt to equity ratio memiliki nilai rata-rata lebih besar dari $0,8300>0,67565$ dan return on asset 
memiliki rata-rata lebih besar dari 15,8411> 14,06736, hal tersebut menunjukkan penyimpangan data yang rendah.

\section{Hasil Asumsi Klasik}

\section{Uji normalitas}

Uji normalitas yang bertujuan untuk menguji apakah model regresi, variabel pengganggu atau residual mempunyai distribusi normal atau tidak. Statistik uji yang digunakan untuk menguji normalitas adalah One-Sample Kolmogorov-Smimov (K-S) Test seperti yang ditunjukkan pada Tabel 3 berikut ini.

Tabel 3. Uji Normalitas

\begin{tabular}{|c|c|c|}
\hline \multicolumn{3}{|c|}{ One-Sample Kolmogorov-Smirnov Test } \\
\hline & & $\begin{array}{l}\text { Unstandardiz } \\
\text { ed Residual }\end{array}$ \\
\hline \multicolumn{2}{|l|}{$\mathrm{N}$} & 135 \\
\hline \multirow[t]{2}{*}{ Normal Parameters $^{\mathrm{a}, \mathrm{b}}$} & Mean & ,0000000 \\
\hline & $\begin{array}{l}\text { Std. } \\
\text { Deviation }\end{array}$ & 20,83336345 \\
\hline \multirow{3}{*}{$\begin{array}{l}\text { Most Extreme } \\
\text { Differences }\end{array}$} & Absolute &, 062 \\
\hline & Positive & ,062 \\
\hline & Negative &,- 047 \\
\hline \multicolumn{2}{|l|}{ Kolmogorov-Smirnov Z } & ,062 \\
\hline \multicolumn{2}{|l|}{ Asymp. Sig. (2-tailed) } & 200 \\
\hline \multicolumn{3}{|c|}{ a. Test distribution is Normal. } \\
\hline \multicolumn{3}{|l|}{ b. Calculated from data. } \\
\hline
\end{tabular}

Pengujian normalitas menggunakan uji Kolmogorov - Smirnov menunjukkan tingkat signifikansi sebesar 0,200. Angka ini lebih besar dari $\alpha=0,05$ maka dapat disimpulkan bahwa model regresi yang digunakan memiliki distribusi data normal.

\section{Uji multikolinearitas}

Uji multikolinearitas bertujuan untuk menguji apakah model regresi ditemukan adanya korelasi antarvariabel bebas. Hasil uji multikolinearitas dapat dilihat dari nilai tolerance dan variance inflaction factor (VIF) seperti yang ditunjukkan pada Tabel 4 berikut ini.

Tabel 4. Uji Multikolinearitas

\begin{tabular}{|ll|r|r|}
\hline \multirow{2}{*}{ Model } & \multicolumn{2}{|c|}{ Collinearity Statistics } \\
\cline { 3 - 4 } & & Tolerance & \multicolumn{1}{c|}{ VIF } \\
\hline 1 & (Constant) &, 908 & 1,101 \\
\cline { 2 - 4 } & CR &, 901 & 1,110 \\
\cline { 2 - 4 } & DER &, 991 & 1,010 \\
\cline { 2 - 4 } & ROA & \multicolumn{2}{c}{} \\
\hline
\end{tabular}


Sumber : Data diolah peneliti, 2017.

Berdasarkan hasil pengujian yang ditunjukkan pada Tabel 4, nilai tolerance variabel bebas tidak kurang dari $10 \%$ atau 0,1 dan nilai variance inflation factor (VIF) semuanya kurang dari 10 yang berarti tidak ada multikolineritas antarvariabel bebas.

\section{Uji autokorelasi}

Uji autokorelasi bertujuan untuk menguji apakah dalam suatu model regresi ada korelasi antara kesalahan pengganggu pada periode $t$ dengan kesalahan pada periode $t-1$. Untuk dapat mengetahui adanya autokorelasi dilakukan dengan metode Durbin-Watson (DW). Hasil uji DW dapat dilihat pada Tabel 5 berikut ini.

Tabel 5. Uji Autokolerasi

\begin{tabular}{|l|r|r|r|r|r|}
\hline Model & $\mathrm{R}$ & R Square & $\begin{array}{c}\text { Adjusted R } \\
\text { Square }\end{array}$ & $\begin{array}{l}\text { Std. Error of } \\
\text { the Estimate }\end{array}$ & $\begin{array}{c}\text { Durbin- } \\
\text { Watson }\end{array}$ \\
\hline 1 &, $362^{\mathrm{a}}$ &, 131 &, 111 & 21,07056 & 1,771 \\
\hline
\end{tabular}

Sumber : Data diolah peneliti, 2014.

Hasil uji autokorelasi menunjukkan nilai Durbin-Watson yang diperoleh adalah sebesar 1,771. Nilai ini terletak diantara DU $<$ DW $<4$-DU yaitu $1,845<1,771<2,303$ sehingga dapat disimpulkan bahwa dalam model regresi tidak terdapat masalah autokorelasi.

\section{Uji heteroskedastisitas}

Uji heteroskedastisitas bertujuan untuk menguji apakah dalam model regresi terjadi ketidaksamaan variance dari residual suatu pengamatan ke pengamatan yang lain. Pengujian heteroskedastisitas pada penelitian ini dilakukan dengan menggunakan uji Glejser yang ditunjukkan pada Tabel 6 berikut ini :

Tabel 6. Uji Heteroskedastisitas

Coefficients ${ }^{\mathrm{a}}$

\begin{tabular}{|c|c|c|c|c|c|c|}
\hline \multirow{2}{*}{\multicolumn{2}{|c|}{ Model }} & \multicolumn{2}{|c|}{$\begin{array}{c}\text { Unstandardized } \\
\text { Coefficients }\end{array}$} & \multirow{2}{*}{$\begin{array}{c}\begin{array}{c}\text { Standardized } \\
\text { Coefficients }\end{array} \\
\text { Beta }\end{array}$} & \multirow[b]{2}{*}{$\mathrm{t}$} & \multirow[b]{2}{*}{ Sig. } \\
\hline & & $\mathrm{B}$ & Std. Error & & & \\
\hline \multirow[t]{4}{*}{1} & (Constant) & 14,562 & 2,408 & & 6,047 & ,000 \\
\hline & CR &, 151 & ,232 & 059 & ,649 &, 517 \\
\hline & DER &,- 188 & 1,761 &,- 010 &,- 107 & ,915 \\
\hline & $\mathrm{ROA}$ &, 086 & ,081 & ,093 & 1,066 & ,288 \\
\hline
\end{tabular}

Sumber : Data diolah peneliti, 2014.

Hasil pengujian menunjukkan seluruh variabel bebas tidak berpengaruh pada nilai absolut residual yang dilihat dari nilai signifikan masing-masing variabel bebas diatas 0,05 . Hal ini berarti model regresi bebas dari heteroskedastisitas.

\section{Hasil Analisis dan Pengujian Hipotesis}


Hasil analisis pengujian dengan menggunakan program SPSS 22 dirangkum dalam tabel 7 berikut ini.

Tabel 7. Hasil Analisis dan Pengujian Hipotesis

Coefficients $^{\text {a }}$

\begin{tabular}{|c|c|c|c|c|c|c|}
\hline \multirow{2}{*}{\multicolumn{2}{|c|}{ Model }} & \multicolumn{2}{|c|}{$\begin{array}{c}\text { Unstandardized } \\
\text { Coefficients }\end{array}$} & \multirow{2}{*}{$\begin{array}{c}\text { Standardized } \\
\text { Coefficients } \\
\text { Beta } \\
\end{array}$} & \multirow[b]{2}{*}{$\mathrm{t}$} & \multirow[b]{2}{*}{ Sig. } \\
\hline & & B & Std. Error & & & \\
\hline \multirow[t]{4}{*}{1} & (Constant) & 43,965 & 3,882 & & 11,325 & ,000 \\
\hline & CR & ,613 & ,374 &, 140 & 1,638 & , 104 \\
\hline & DER & $-9,734$ & 2,839 &,- 294 & $-3,429$ & 001 \\
\hline & ROA & ,101 &, 130 &, 064 & ,779 & ,437 \\
\hline \multicolumn{2}{|c|}{ Adjusted $\mathrm{R}^{2}$} & \multicolumn{5}{|l|}{$=0,111$} \\
\hline \multicolumn{2}{|c|}{ F-test } & \multicolumn{5}{|l|}{$=6,581$} \\
\hline \multicolumn{2}{|c|}{ Signifikansi F } & \multicolumn{5}{|l|}{$=0,000$} \\
\hline
\end{tabular}

a. Dependent Variable: DPR

Sumber : Data diolah peneliti, 2014.

Berdasarkan Tabel 7 diatas terlihat bahwa nilai adjusted $\mathrm{R}^{2}$ adalah 0,111 atau 11,1 persen. Ini berarti varian variabel bebas cash ratio, debt to equity ratio, dan return on asset memengaruhi variabel terikat dividend payout ratio sebesar 11,1 persen sedangkan sisanya 88,9 persen dipengaruhi oleh variabel lain yang tidak dimasukkan dalam model. Nilai F test digunakan untuk melihat hubungan variabel bebas dengan variabel terikat sebesar 6,581 dengan signifikansi 0,000. Angka signifikansi tersebut lebih kecil dari 0,05, hal ini berarti model yang digunakan dalam penelitian ini adalah layak.

Dilihat dari Tabel 7 diatas maka dapat disusun persamaan regresi linear berganda sebagai berikut.

$$
\mathrm{DPR}=\text { 43,965 + 0,374CR - 2,839DER + 0,130 ROA + } \varepsilon
$$

Hasil pengujian masing-masing variabel independen terhadap variabel dependennya dapat dijelaskan sebagai berikut.

1) Variabel cash ratio

Dari hasil penghitungan uji-t diperoleh nilai $\mathrm{t}$ hitung sebesar 1,638 dengan nilai signifikansi sebesar 0,104 . Karena nilai t hitung $(1,638)$ lebih besar dari nilai t tabel $(1,978)$ dan nilai signifikansi lebih kecil dari $5 \%$ yaitu sebesar $0,3 \%$ maka hipotesis 1 diterima. Ini berarti bahwa variabel cash ratio berpengaruh positif dan signifikan secara statistik terhadap dividend payout ratio. Tanda positif pada koefisien menunjukkan bahwa meningkatnya nilai cash ratio pada umumnya akan meningkatkan dividend payout ratio.

2) Variabel debt to equity ratio

Hasil penghitungan uji t diperoleh nilai t hitung sebesar -3,429 dengan nilai signifikansi sebesar 0,001. Karena nilai t hitung $(-3,429)$ lebih kecil dari t tabel $(1,978)$ dan nilai signifikansi lebih kecil dari $5 \%$ yaitu sebesar $0,1 \%$ maka hipotesis 2 diterima. Ini berarti bahwa variabel debt to equity ratio berpengaruh negatif dan signifikan secara statistik 
terhadap dividend payout ratio. Tanda negatif yang terdapat pada koefisien regresi menunjukkan bahwa menurunnya nilai debt to equity ratio pada umumnya akan menyebabkan peningkatan dividend payout ratio.

3) Variabel return on asset

Hasil pengujian uji t diperoleh nilai t hitung sebesar 0,779 dengan nilai signifikansi sebesar 0,437. Karena nilai t hitung $(0,779)$ lebih besar dari t tabel $(1,978)$ dan nilai signifikansi lebih kecil dari 5\% yaitu sebesar 43,7\% maka hipotesis 3 diterima. Hal ini berarti bahwa variabel return on asset berpengaruh positif dan signifikan secara statistic terhadap dividend payout ratio. Tanda positif yang terdapat pada koefisien regresi menunjukkan bahwa setiap peningkatan nilai return on asset pada umumnya akan menyebabkan meningkatnya dividend payout ratio.

\section{Pengaruh cash ratio (X1) terhadap dividend payout ratio (Y)}

Hasil pengujian hipotesis menunjukkan bahwa cash ratio berpengaruh positif dan signifikan secara statistik terhadap dividend payout ratio. Variabel cash rasio memiliki koefisien positif, ini berarti bahwa apabila cash ratio meningkat maka kemungkinan dibagikannya dividen akan semakin besar. Hasil pengujian ini konsisten dengan hasil penelitian yang dilakukan oleh Sutrisno (1999) yang menguji faktor-faktor yang berpengaruh terhadap dividend payout ratio.

Penelitian tersebut menggunakan sampel dari perusahaan publik yang listed di Bursa Efek Jakarta periode tahun 1991-1996. Hasil penelitian tersebut menunjukkan bahwa variabel cash ratio berpengaruh positif terhadap dividend payout ratio. Hasil penelitian ini juga juga mendukung penelitian yang dilakukan oleh Andriyani (2008) yang melakukan penelitian mengenai faktor-faktor yang mempengaruhi dividend payout ratio pada perusahaan otomotif yang listed di Bursa Efek Indonesia periode 2002-2004. Hasil penelitian tersebut menunjukkan bahwa variabel cash ratio mempunyai pengaruh yang positif terhadap dividend payout ratio. Hasil penelitian lainnya yang mendukung hasil penelitian ini adalah penelitian yang dilakukan oleh Prihantoro (2003) yang menyimpulkan bahwa posisi kas perusahaan berpengaruh positif dan signifikan terhadap dividend payout ratio. Sunarto dan Kartika (2003) dan Chasanah (2008) melakukan penelitian yang menghasilkan kesimpulan yang berbeda dengan hasil penelitian ini.

Penelitian yang dilakukan oleh Sunarto dan Kartika (2003) menghasilkan kesimpulan bahwa cash ratio tidak berpengaruh signifikan terhadap terhadap dividend payout ratio, pada penelitian yang dilakukan oleh Chasanah (2008) menunjukkan hasil bahwa cash ratio berpengaruh positif dan tidak signifikan terhadap dividend payout ratio pada perusahaan yang sebagian sahamnya dimiliki manajemen sedangkan cash ratio berpengaruh negatif dan tidak signifikan terhadap dividen payout ratio`pada perusahaan yang sahamnya tidak dimiliki manajemen.

Nilai positif dalam variabel cash ratio ini menunjukkan bahwa adanya peningkatan jumlah kas dan setara kas dalam perusahaan maka akan meningkatkan dividend payout ratio. Semakin likuid perusahaan maka akan semakin besar kemungkinan pembayaran yang dilakukan oleh perusahaan tersebut. Meningkatnya cash ratio juga dapat meningkatkan harapan investor terhadap kemampuan perusahaan untuk membagikan dividen. Mollah dan Keasen (2000) menyatakan bahwa cash ratio merupakan variabel penting yang dipertimbangkan oleh manajemen dalam penentuan kebijakan dividen. Pembayaran dividen merupakan arus kas keluar sehingga free cash 
flow yang tinggi akan memungkinkan perusahaan lebih berfokus pada pembiayaan dividen atau pelunasan hutang untuk mengurangi biaya keagenan (Mollah dan Keasen,2000).

\section{Pengaruh debt to equity ratio (X2) terhadap dividend payout ratio (Y)}

Hasil pengujian hipotesis menunjukkan bahwa debt to equity ratio berpengaruh negatif terhadap debt to equity ratio. Semakin rendah DER akan semakin tinggi kemampuan perusahaan untuk membayar seluruh kewajibannya. Hal ini disebabkan karena semakin besar proporsi hutang yang digunakan untuk struktur modal suatu perusahaan, maka akan semakin besar pula jumlah kewajibannya. Peningkatan hutang pada gilirannya akan memengaruhi besar kecilnya laba bersih yang tersedia bagi para pemegang saham termasuk dividend yang akan diterima, karena kewajiban tersebut lebih diprioritaskan daripada pembagian dividen. Jika beban hutang semakin tinggi, maka kemampuan perusahaan untuk membagi dividen akan semakin rendah, sehingga DER mempunyai pengaruh negatif dengan dividend payout ratio. Dilihat dari perkembangan periode pengamatan, perusahaan manufaktur rata-rata memiliki nilai debt to equity ratio yang rendah, hal ini menunjukkan bahwa perusahaan manufaktur lebih menyukai pmbiayaan dengan modal sendiri daripada menggunakan dana dari pihak luar. Hal tersebut sejalan dengan pecking order theory yang menyatakan bahwa perusahaan menyukai internal financing (pendanaan dari hasil operasi perusahaan berwujud laba ditahan) daripada pendanaan dari luar. Hal ini tidak terlepas dari usaha untuk meningkatkan kredibilitas perusahaan di mata pihak eksternal karena hutang memberikan risiko yang tinggi, artinya perusahaan harus mampu mengambil keputusan di tengah tawaran akan manfaat dari leverage atau menjaga kesejahteraan pemegang saham, dengan menjauhkannya dari risiko tersebut.

Hasil pengujian penelitian ini konsisten dengan hasil penelitian sebelumnya yang dilakukan oleh Ismiyanti dan Hanafi (2004) yang meneliti tentang pengaruh kebijakan utang, kepemilikan manajerial, risiko dan kepemilikan institusional dengan variabel kontrol ROA dan IOS (Investment Opportunity Set) yang diproksi dengan Book Value Equity/ Market Value Equity) terhadap dividen.

Hasil penelitian tersebut menyimpulkan bahwa kebijakan hutang (diproksi dengan leverage) berpengaruh negatif terhadap kebijakan dividen. Hasil penelitian ini juga mendukung penelitian yang dilakukan oleh Prihantoro (2003), Andriyani (2008), dan Appannan dan Sim (2011). Prihantoro (2003) yang meneliti tentang estimasi pengaruh dividend payout ratio pada perusahaan publik di Indonesia menyatakan bahwa debt equity ratio mencerminkan kemampuan perusahaan dalam memenuhi seluruh kewajibannya, yang ditunjukkan oleh berapa bagian modal sendiri yang digunakan untuk membayar hutang. Oleh karena itu, semakin rendah DER akan semakin tinggi kemampuan perusahaan untuk membayar semua kewajibannya. Jika beban hutang tinggi, maka kemampuan perusahaan untuk membagi dividen akan semakin rendah sehingga DER mempunyai hubungan negatif dengan dividend payout ratio. Andriyani (2008) menghasilkan kesimpulan bahwa debt to equity ratio berpengaruh negatif dan signifikan terhadap dividend payout ratio. Kesimpulan ini didapat setelah meneliti pengaruh cash ratio, debt to equity ratio, insider ownership, investment opportunity set, dan profitability terhadap kebijakan dividen yang dilakukan pada perusahaan otomotif yang listed di Bursa Efek Indonesia. Appannan dan Sim (2011) meneliti faktor-faktor yang mempengaruhi kebijakan dividen pada lima perusahaan yang masuk kedalam kategori industri pengolahan makanan (konsumsi) yang listed di Kuala Lumpur Stock Exchange. Hasil dari penelitian menunjukkan bahwa variabel debt 
to equity ratio dan past dividend per share adalah variabel yang paling kuat berpengaruh terhadap dividend payout ratio.

\section{Pengaruh return on asset (X3) terhadap dividend payout ratio (Y)}

Pada variabel ini tanda positif pada koefisien regresi menunjukkan bahwa apabila return on asset meningkat maka dividend payout ratio juga meningkat. Hasil penelitian menunjukkan bahwa pengaruh positif variabel return on asset terhadap dividend payout ratio menjelaskan bahwa tingkat profitabilitas perusahaan akan berdampak pada peningkatan pembagian dividen yang akan dibayarkan. Tanda positif dalam penelitian ini sesuai dengan teori information content or signaling hypothesis yang dikemukan oleh Miller dan Mondigliani dalam Sartono (2010) yang menyatakan bahwa kenaikan dividen merupakan suatu sinyal kepada para investor bahwa manajemen meramalkan suatu penghasilan yang baik di masa yang akan datang. Berdasarkan teori tersebut, dapat ditunjukkan bahwa penghasilan yang tinggi melalui asset yang dimiliki yang tercermin dari nilai return on asset menunjukkan pengaruh yang positif terhadap kebijakan dividen. Dalam perkembangannya rata-rata return on asset pada industri manufaktur menunjukkan hasil yang baik (data terlampir). Hal ini disebabkan oleh meningkatnya kemampuan perusahaan untuk menghasilkan laba yang tentunya akan meningkatkan nilai perusahaan dan memberikan sinyal baik kepada investor tentang kemampuan perusahaan untuk menghasilkan laba.

Hasil penelitian ini konsisten dengan hasil penelitian sebelumnya yang dilakukan oleh Amidu dan Abor (2006), Anil dan Kapoor (2008), dan Puspita (2009). Amidu dan Abor (2006) meneliti tentang faktor-faktor yang memengaruhi dividend payout ratio pada 22 perusahaan yang listed di Ghana Stock Exchange pada periode tahun 1998-2003. Hasil penelitiannya menunjukkan bahwa profitabilitas berpengaruh positif terhadap dividend payout ratio. Anil dan Kapoor (2008) melakukan penelitian tentang faktor-faktor yang memengaruhi dividend payout ratio pada perusahaan-perusahaan IT di India. Hasil penelitian Anil dan Kapoor (2008) menunjukkan bahwa variabel profitabilitas berpengaruh positif terhadap dividend payout ratio. Puspita (2009) melakukan penelitian tentang faktor-faktor yang memengaruhi kebijakan dividen dengan studi kasus pada perusahaan yang terdaftar di Busa Efek Indonesia periode 2005-2007.

Hasil penelitian tersebut menunjukkan bahwa variabel return on asset berpengaruh positif dan signifikan terhadap dividend payout ratio. Hasil penelitian kali ini bertolak belakang dengan hasil penelitian sebelumnya. Damayanti dan Achyani (2006) yang melakukan penelitian terhadap seluruh perusahaan manufaktur yang terdaftar di Bursa Efek Jakarta periode 1999-2003 dengan menguji pengaruh antara variabel independen investasi perusahaan, likuiditas, profitabilitas, pertumbuhan perusahaan, ukuran perusahaan dan variabel dependen dividen payout ratio. Hasil penelitian menunjukkan bahwa variabel profitabilitas tidak berpengaruh siginifikan terhadap dividend payout ratio.

\section{Kesimpulan}

Berdasarkan hasil pengujian hipotesis, maka dapat disimpulkan hal-hal berikut ini:

1) Cash ratio berpengaruh positif dan signifikan terhadap dividend payout ratio. Hal ini berarti setiap peningkatan nilai cash ratio maka pada umumnya akan terjadi pula peningkatan pada 
nilai dividend payout ratio. Jumlah kas dan setara kas yang dipunyai perusahaan juga secara tidak langsung akan mencerminkan kemampuan perusahaan untuk membagi dividen kepada para pemegang saham.

2) Debt to equity ratio berpengaruh negatif dan signifikan terhadap dividend payout ratio. Hal ini berarti dengan rendahnya nilai debt to equity ratio perusahaan maka pada umumnya kemampuan perusahaan untuk membayar dividen akan semakin tinggi. Peningkatan dan penurunan hutang sangat mempengaruhi jumlah laba bersih yang pada akhirnya akan mempengaruhi nilai laba ditahan yang tercatat, jika nilai hutang tinggi tentu saja akan mempengaruhi kemampuan perusahaan untuk membagikan dividen.

3) Return on asset berpengaruh signifikan terhadap dividend payout ratio. Hal ini bermakna bahwa setiap kenaikan nilai return on asset maka pada umumnya akan meningkatkan kemampuan perusahaan untuk membayarkan dividen kepada pemegang saham. Ini disebabkan karena meningkatnya kemampuan profitabilitas perusahaan maka akan diikuti kemampuan perusahaan dalam menghasilkan laba bersih yang tinggi, yang pada akhirnya akan mempengaruhi jumlah dividen yang akan dibagikan kepada para pemegang saham.

\section{Referensi}

Damayanti, S. dan Achyani, F. (2006). Analisis Pengaruh Investasi, Likuiditas, Profitabilitas, Pertumbuhan Perusahaan, dan Ukuran Perusahaan terhadap Kebijakan Dividen Payout Ratio. Jurnal Akuntansi dan Keuangan, 5(1), 51-62.

Dyckman, T. R., Roland E. D., Charles, J. D. (2002). Akuntansi Intermediate. Edisi Kesepuluh. Jilid I. Terjemahan Emil Salim. Jakarta: Erlangga.

Elloumi, F. dan Jena-Pierre Gueyle, J. (2003). "CEO Compensation, IOS, and The Role of Corporate Governance,” Corporate Governance, (1)2, 23-33.

Gaver, J. J. dan Gaver, K. M. (1993). "Additional Evidence on The Association Between The Investment Opportunity Set and Corporate Financing, Dividend and Compensation Policies, Journal of Accounting and economics, 1, 233-265.

Ghozali, I. (2007). Aplikasi Analisis Multivariate Dengan Program SPSS. Edisi II. Semarang: Badan Penerbit Universitas Diponegoro.

Gill, Amarjit., Biger, N. dan Tibrewala, R. (2010). Determinants of Dividend Payout Ratios: Evidence fro United States. The Open Business Journal, 3, 8-14.

Gitman, L. J. (2003), Principles of Managerial Finance. Edisi Kesepuluh. Massachusetts: Addison Wesley Publishing Company.

Hafeez, A. dan Javid, A. Y. (2009). The Determinants of Dividend Policy in Pakistan. International Research Journal of Finance and Economics, 29.

Hanafi, M. M. dan Halim, A. (2009). Analisis Laporan Keuangan. Edisi Keempat. Yogyakarta: YKPN.

Harahap. (2012). Analisis Kinerja Keuangan dan Perencanaan Keuangan Perusahaan. Jakarta: Gramedia Pustaka Utama. 
IJBE: Integrated Journal of Business and Economics e-ISSN: 2549-3280

Harahap, S. S. (2009). Analisis Kritis atas Laporan Keuangan. Jakarta: Rajawali Pers.

Harahap, S. S. (2010). Teori Akuntansi Edisi Revisi 2011. Jakarta: PT Raja Grafindo Persada.

Hatta, A. J. (2002). Faktor-faktor yang Mempengaruhi Kebijakan Dividen: Investasi Pengaruh Teori Stakeholder. JAAI, (6)2.

Helfert, E. A. (1993). Analisa Laporan Keuangan. Edisi Ketujuh. Terjemahan oleh Herman Wibowo. Jakarta: Erlangga.

Ghozali, I. (2005). Aplikasi Analisis Multivariate Dengan Program SPSS, Semarang: Badan Penerbit UNDIP.

Ismiyanti, F. dan Hanafi, M. (2003). Kepemilikan Manajerial, Kepemilikan Institutional, Risiko, Kebijakan Hutang dan Kebijakan Dividen: Analisa Persamaan Simultan," Makalah Seminar, Simposium Nasional Akuntansi VI, Ikatan Akuntansi Indonesia, 260-276.

Jensen, M., and Meckling, W. (1976). Theory of the Firm: Managerial Behavior, Agency, and Ownership Structure, Journal of Financial Economics, 305-360.

Jensen, S. and Zorn. (1992). Simultaneous Determination of Insider Ownership, Debt and Dividend policies, Journal of Financial and Quantitative Analysis, (27)2, 247-263.

Karen, F.R. (2003). A Blue Print for Corporate Governance. New York: American Management Assosiation.

Wibowo, H. (1995). Akuntansi Intermediate. Edisi ke 7. Jakarta:. Bina Rupa Aksara.

Mahadwartha, P. A. dan Jogiyanto, H. (2002). Uji Teori Keagenan Dalam Hubungan Interdependensi Antara Kebijakan Hutang dan Kebijakan Dividen, Makalah Seminar, Simposium Nasional Akuntansi V, Ikatan Akuntansi Indonesia, p.635-647 .

Manurung, I. A. dan Siregar, H. S. (2009). Pengaruh Laba Bersih Dan Arus Kas Operasi Terhadap Kebijakan Dividen. Jurnal Akuntansi 3.

Martono dan Harjito, A. (2002). Manajemen Keuangan, Edisi Pertama, Cetakan Kedua, Yogyakarta: Ekonista.

Kasmir. (2012). Analisis Laporan Keuangan. Jakarta: PT. Raja Grafindo Persada.

Prihantoro. (2003). Estimasi Pengaruh Dividen Payout Ratio pada Perusahaan Publik di Indonesia. Jurnal Ekonomi dan Bisnis, (1)8.

Puspita, F. (2009). “Analisis Faktor-faktor yang Mempengaruhi Kebijakan Dividend Payout Ratio (Studi Kasus pada Perusahaan yang Terdaftar di Bursa Efek Indonesia Periode 2005-2007)" "(tesis). Semarang : Universitas Diponegoro Semarang. 